Research Article

\title{
Phytochemical analysis and HPLC estimation of phytoconstituents of Buchanania lanzan Spreng
}

\author{
Jyoti Shrivastava*, T. Ratna Madhuri \\ Department of Pharmaceutical Chemistry, \\ The Oxford College of Pharmacy, Hongasandra, Bangalore-560068, Tamil Nadu, India
}

Received: 14 September 2019

Revised: 11 October 2019

Accepted: 18 October 2019

\begin{abstract}
Objective: The present study was designed to investigate cytotoxic active principles from crude extract of Buchanania lanzan Spreng based on its ethnobotanical information. The objectives of study are; collection of plant material, extraction and preliminary phytochemical evaluation and preformation of HPLC finger printing of extracts. Materials and methods: The bark of Buchanania lanzan Spreng was extracted with different solvents by soxhlet method and screened for the presence of its phytochemical composition. The ethanolic and ethyl acetate extracts were selected due to its high percentage yield for HPLC fingerprinting. Results: The bark of Buchanania lanzan Spreng showed the presence carbohydrates, alkaloids, flavonoids, saponins, proteins, amino acids and phenolic compounds. The comparative study of total flavanoid content and total phenolic content of ethanolic and ethyl acetate extracts shows that ethyl extracts had higher content of galic acid and quercetin as compared to ethanolic extract. Conclusion: Phenols are the compound which proves to enhance the body's immune system there by inhibiting the development of new blood vessels (angiogenesis) that is necessary for tumor growth. The present study proved that bark extracts of Buchanania lanzan Spreng had higher content of phenols and flavanoids into it and hence it can be a potent anticancerous herbal drug in future.
\end{abstract}

Keywords: Buchanania lanzan, anticancer, HPLC, phenols, flavonoids, quercetin, galic acid

\section{Introduction}

Cancer is a major public health burden in both developed and developing countries. Several synthetic agents are used to cure the disease but they have their toxicity like bone marrow toxicity, neurotoxicity etc and hence the research is going on to investigate the plant derived chemotherapeutic agents (Hossein and Hassanpour, 2017: Kooti et al., 2017; Kumari and Kakkar, 2008).

In recent times, plants research has increased all over the world and evidences has been collected to show immense potential of medicinal plants used in various traditional system. Many traditional healers and herbalists in the India have been treating cancer patients for many years using various medicinal plant species. Hence, an attempt has been made to screen

\section{*Address for Corresponding Author:}

Dr. Jyoti Shrivastava,

The Oxford College of Pharmacy, Hongasandra, Bangalore-560068, Tamil Nadu, India

E-mail:jyotishrivastavapharmacy@gmail.com
Buchanania lanzan Spreng for the prevention and treatment of cancer (Kapoor, 2000; Mehta et al., 2011; Jain and Jain, 2015; Warokar et al., 2010).

Naturally occurring substances of plant origin and dietary components that have been widely studied for their antimutagenic activity, which includes carotenoids, flavonoids, tea-polyphenols, vitamins, cucuminoids, tannins, coumarins, chlorophyllin, porphyrins and alkylresorcinols from cereal grains (Rai, 2010; Mehta, 2011; Puri et al., 2000). Phenols are the compound which proves to enhance the body's immune system there by inhibiting the development of new blood vessels (angiogenesis) that is necessary for tumour growth (Pattnaik et al., 2013; Perveen et al., 2017; Selassie et al., 2013), while flavonoids modulate signal transduction pathways within cancer cells resulting in angiogenesis and metastasis within the cell. It also promotes apoptosis (Chang et al., 2008; Katrin, 2014; Kuntz et al., 1999). Hence, an attempt has been made for accurate scientific

DOI: https://doi.org/10.31024/apj.2019.4.5.1

2456-1436/Copyright (C) 2019, N.S. Memorial Scientific Research and Education Society. This is an open access article under the CC BYNC-ND license (http://creativecommons.org/licenses/by-nc-nd/4.0/). 
documentation of phenolic and flavonoid content of Buchanania lanzan Spreng bark extracts by HPLC method to establish its claim for the prevention and treatment of cancer.

\section{Materials and methods}

\section{Plant material}

The stem bark of Buchanania lanzan was collected and the plant specimen was authenticated by Dr. K. Madhava Chetty, assistant professor, Department of Botany, SV University, Tirupati (A.P). The voucher no. for the specimen is 1123. A voucher specimen has been preserved in the laboratory for future reference.

\section{Preparation of crude extract and phytochemical screening}

The stem bark of the plant was dried in shade for about 3 weeks and grinded by using a electric mixer to a coarse powder. Powders of stem barks are first extracted with the petroleum ether $\left(60-80^{\circ} \mathrm{C}\right)$ for defatting. The successively re-extraction had been performed with various solvents in increasing polarity for $48 \mathrm{hrs}$ in a soxhlet extraction apparatus. The resulting extracts were filtered through whatman no 1 filter paper and then concentrated about one tenth the original volume in a water bath $\left(40^{\circ} \mathrm{C}\right)$ for complete dryness. The extract was refrigerated at $2-$ $8^{\circ} \mathrm{C}$ until use.

\section{Instrumentation}

The HPLC system, Shimadzu, Japan was used for the study with shimadzu LC-10ATVP, pump, shimadzu spd10A uv-vis detector, phenomenex gemini-NX-5 $\mu \mathrm{m}$ C18(2) $110 \AA$, LC column $250 \times 4.6 \mathrm{~mm}$ column and baseline chromatography DSN2000 software.

\section{Phytochemical Screening}

The chemical tests were performed for screening of different chemical groups present in extracts.

\section{Test for carbohydrates}

Molisch's test: A test tube containing extract of drug was added with two drop of freshly prepared $20 \%$ alcoholic solution of alpha napthol and mixed con. $\mathrm{H}_{2} \mathrm{SO}_{4}$ was added from the side wall of the test tube. Colour at the junction of the two liquids was observed.

Benedict's test: A test tube containing extract of drug was added with benedict's solution, mixed well and boiled vigorously for two minutes and then cooled. The colour of the precipitate was observed.

Fehling's test (Reducing sugars): To $2 \mathrm{ml}$ of extract, equal volume of mixture of equal parts of Fehling's solution A and B were added and boiled for few minutes in boiling water bath. Formation of red or brick red coloured precipitate indicated the presence of reducing sugars.

\section{Test for alkaloids}

Dragendorff's Test: A test tube containing extract of the drug was added with $5 \mathrm{ml}$ of water mixed with $2 \mathrm{M}$ hydrochloric acid. To this $1 \mathrm{ml}$ of dragendorff's reagent (potassium bismuth iodide solution) was added from the side wall of the test tube. Color at the junction of the two liquids was observed.

Wagner's test: A test tube containing extract of drug was added with $1.5 \% \mathrm{v} / \mathrm{v}$ of hydrochloric acid and few drop of Wagner's reagent. The color of the precipitate was observed.

Mayer's Test: The Mayer's reagent was added to $2 \mathrm{ml}$ of extract solution and the color of the precipitate was observed.

Hager's Test: A test tube containing extract of drug was added with $3 \mathrm{ml}$ of Hager's reagent. Color at the junction of the two liquids was observed.

\section{Test for steroids and sterols}

Liebermann's Burchard reaction: A test tube containing extract of drug was mixed with $2 \mathrm{ml}$ of chloroform and added 10 drops of acetic anhydride followed by 2 drops of con. $\mathrm{H}_{2} \mathrm{SO}_{4}$. The change in colour of solution was observed.

Salkowsky test: A test tube containing extract of drug was mixed with equal volume of chloroform and con. $\mathrm{H}_{2} \mathrm{SO}_{4}$ was added. The change in color of acid and chloroform layer was observed.

\section{Test for glycosides}

Legal's test: A test tube containing extract of drug was mixed with pyridine then sodium nitroprusside solution was added. The change in colour of solution was observed.

Borntrager's test: A test tube containing extract of drug was added with few $\mathrm{ml}$ of dil. $\mathrm{H}_{2} \mathrm{SO}_{4}$ and boiled with ether or chloroform. To the separated organic layer, ammonia was added and change in colour was observed.

Keller Kiliani test: A test tube containing extract of drug was added with $\mathrm{C}_{2} \mathrm{H}_{4} \mathrm{O}_{2}$. To this $1 \mathrm{ml}$ con $\mathrm{H}_{2} \mathrm{SO}_{4}$ was added from the side wall of the test tube. Colour at the junction of the two liquids was observed.

\section{Test for flavonoids}

Shinoda test: A test tube containing extract of drug was added with 10 drops of dil. hydrochloric acid followed by the small piece of magnesium and the color was observed.

Alkaline reagent test: To $2 \mathrm{ml}$ of test solution add $2 \mathrm{ml}$ alkali, gives yellow color, which disappears on addition of 
dil $\mathrm{HCl}$ it disappears, which indicates presence of flavonoids.

Test of saponins (Foam Test): A test tube containing $1 \mathrm{ml}$ extract of drug was added with $20 \mathrm{ml}$ distilled water in graduated cylinder for 15 minutes. Formation of foam layer was observed.

\section{Test for Phenolic and tannins}

Ferric chloride test: Extract solutions were treated with 5\% ferric chloride solution. Formation of blue colours indicated the presence of hydrolysable tannins and formation of green colour indicated the presence of condensed tannins.

Gelatin test: $3 \mathrm{ml}$ of test solution when treated with gelatin solution ( $3 \mathrm{ml})$ gave white precipitate.

Lead Acetate test: A test tube containing extract of drug was added with two $\mathrm{ml}$ of $40 \%$ sodium hydroxide solution and boiled followed by glacial acetic acid and $1 \mathrm{ml}$ of lead acetate solution. The change in colour of solution was observed after cooling.

\section{Test for protein and amino acid}

Biuret test: A test tube containing extract of drug was added with $1 \mathrm{ml}$ of $40 \% \mathrm{NaOH}$ solutions and two drops of $1 \% \mathrm{Cu}_{2} \mathrm{SO}_{4}$ solution. The change in colour of solution was observed.

Ninhydrin's test: 2 drops of freshly prepared $0.2 \%$ ninhydrin reagent was added to extract of drug and heated to boiling for 2 min. The change in colour of solution was observed after cooling.

Xanthoprotein test: A test tube containing extract of drug was added with conc. nitric acid. The change in colour of precipitate was observed.

Millon's test: Six drops of Millon's reagent was added to the extract of drug and the colour was observed.

Test of resins: A test tube containing extract of drug was added with acetone and distilled water. The turbidity of the solution was observed.

Test of fats or fixed oils (Saponification): Four $\mathrm{ml}$ of $2 \%$ sodium carbonate solution was mixed with extract of the drug and boiled. To soapy solution few drops of conc. $\mathrm{HCl}$ was added and observed for fatty precipitate formation.

\section{Determination of percentage yield}

The percentage yield of each extract was calculated by using following formula:

Percentage yield $=\{$ Weight of Extract/ Weight of powder material taken $\}$ x 100

\section{Estimation of Gallic acid by Rp-HPLC}

Mobile phase preparation: Mobile phase was prepared by mixing Methanol: Water $(60: 40)$. pH of the solution was adjusted to 3.5 with dilute phosphoric acid .This solution was filtered using a 0.45 micron Millipore filter paper and was sonicated for
$10 \mathrm{mins}$. The total volume of the mobile phase prepared was $500 \mathrm{ml}$.

Standard preparation: Accurately $10 \mathrm{mg}$ of Gallic acid was taken in $10 \mathrm{ml}$ volumetric flask and make up the volume to $10 \mathrm{ml}$ with methanol (the concentration of this solution is $1000 \mu \mathrm{g} / \mathrm{ml}$ ). From this above solution working solution 20 , $40,60,80$ and $100 \mu \mathrm{g}$ was pipetted into $10 \mathrm{ml}$ volumetric flask and volume was made up to the mark with Methanol. This is a working solution. This was sonicated for 8 minutes then the solution was filtered using 0.45 micron Millipore filters.

Sample preparation: To $1 \mathrm{mg}$ of the given sample was taken in $1 \mathrm{ml}$ of respective solvents. The solution was vortex for $5 \mathrm{mins}$. The sample was filtered using 0.45 micron Millipore filters. $20 \mu 1$ of this sample was injected in the HPLC system.

The concentration of unknown sample was calculated as follows $=$ Sample area/ STD area $\mathrm{x}$ STD wt. $/$ Sample wt. $\mathrm{x}$ Sample dilution/STD dilution $\mathrm{x}$ purity /100 x 100

\section{Estimation of Quercetin by Rp-HPLC}

Mobile phase preparation: Mobile phase was prepared by mixing Methanol: 0.005mM phosphate buffer (70:30). $\mathrm{pH}$ of the solution was adjusted to 3 with dilute phosphoric acid .This solution was filtered using a 0.45 micron Millipore filter paper and was sonicated for $10 \mathrm{mins}$. The total volume of the mobile phase prepared was $500 \mathrm{ml}$.

Standard preparation: $10 \mathrm{mg}$ of Quercetin was taken in $10 \mathrm{ml}$ volumetric flask and make up the volume to $10 \mathrm{ml}$ with methanol (the concentration of this solution is $1000 \mu \mathrm{g} / \mathrm{ml})$. From this above solution working solution 10 , $20,30,40$ and $50 \mu \mathrm{g}$ was pipetted into $10 \mathrm{ml}$ volumetric flask and volume was made up to the mark with Methanol. This is a working solution. This was sonicated for 8 minutes then the solution was filtered using 0.45 micron Millipore filters.

Sample preparation: To $1 \mathrm{mg}$ of the given sample was taken in $1 \mathrm{ml}$ of respective solvents. The solution was vortex for 5 mins. The sample was filtered using 0.45 micron Millipore filters. $20 \mu \mathrm{l}$ of this sample was injected in the HPLC system.

The concentration of unknown sample was calculated as follows $=$ Sple area/ STD area $\mathrm{x}$ STD wt. / Sple wt. $\mathrm{x}$ Sple dilution/STD dilution $\mathrm{x}$ purity /100 x 100 .

\section{Results}

\section{Percentage yield}

As a result of successive solvent extraction the total yield of 
various extracts of Buchanania lanzan bark obtained is tabulated in the table 1. The ethanolic extract of Buchanania lanzan bark showed a highest yield of about $5.55 \mathrm{~g} / 200 \mathrm{~g}(2.7 \%)$, whereas the chloroform extract has showed the lowest yield of $1.8 \mathrm{~g} / 200 \mathrm{~g}(0.8 \%)$.

\section{Phytochemical screening of the plants}

The secondary metabolites and other phytochemical constituents of medicinal plants account for their medicinal value. Hence phytochemical screening plays a major role in all kind of scientific studies. Dried extracts of the plants were subjected to the phytochemical test using methods reported (Khandelwal, 2005; Kokate, 1994; Tiwari et al., 2011) to test for presence of alkaloids, glycosides, tannins, phenols, saponins, flavonoids and terpenoids. Small amount of each extract

Table 1. Total yield of Buchanania lanzan bark extract in various solvents

\begin{tabular}{|c|c|c|}
\hline Solvents & Buchanania lanzan bark & Percentage $(\%)$ \\
\hline Petroleum ether & 1.8 & 0.9 \\
\hline Chloroform & 1.7 & 0.8 \\
\hline Ethyl acetate & 3.1 & 1.5 \\
\hline Ethanol & 5.5 & 2.7 \\
\hline Water & 2.8 & 1.4 \\
\hline
\end{tabular}

Table 2. Phytochemical screening of Buchanania lanzan bark extract

\begin{tabular}{|c|c|c|c|c|c|}
\hline Chemical Tests & Pet. ether & Chloroform & Ethyl acetate & Ethanol & Aqueous \\
\hline \multicolumn{6}{|l|}{ Alkaloids } \\
\hline Mayer's reagent & - & - & - & - & - \\
\hline Hager's reagent & + & - & - & - & - \\
\hline \multicolumn{6}{|l|}{ Wagner's reagent } \\
\hline Dragendorff's reagent & - & - & + & - & - \\
\hline \multicolumn{6}{|l|}{ Glycosides } \\
\hline Legal's test & - & - & - & - & - \\
\hline Keller-Kiliani & - & + & + & + & - \\
\hline Brontager's Test & - & - & + & + & - \\
\hline \multicolumn{6}{|l|}{ Phenols/Tannins } \\
\hline Ferric chloride & - & - & + & + & + \\
\hline Lead acetate test & - & - & + & + & + \\
\hline \multicolumn{6}{|l|}{ Flavonoids } \\
\hline Alkaline reagent test & - & - & + & + & + \\
\hline Shinoda test & - & - & - & + & + \\
\hline \multicolumn{6}{|l|}{ Saponins } \\
\hline Foam test & - & - & + & + & + \\
\hline \multicolumn{6}{|l|}{ Carbohydtrates } \\
\hline Molisch Test & - & - & + & + & + \\
\hline Benidicts Test & - & - & + & + & + \\
\hline Fehlings Test & - & - & + & + & + \\
\hline \multicolumn{6}{|l|}{ Fixed oil/Fats } \\
\hline \multicolumn{6}{|l|}{ Phytosterols } \\
\hline Libermann Burchards Test & + & + & + & - & + \\
\hline Salkowaski Test & + & + & + & - & - \\
\hline \multicolumn{6}{|l|}{ Protein \& Amino acids } \\
\hline Millon's Test & + & - & - & + & - \\
\hline Biuret Test & + & - & - & + & - \\
\hline Ninhydrine Test & + & - & - & + & - \\
\hline Xanthoproteins Test & - & - & - & + & - \\
\hline \multicolumn{6}{|l|}{ Resins } \\
\hline Acetone-Water Test & + & + & - & - & - \\
\hline
\end{tabular}

(+) Indicates 'Presence'; (-) Indicates 'Absence' 
was suitably suspended into the methanol to make the concentration of $1 \mathrm{mg}$ per $\mathrm{ml}$. The outcomes of the results are shown in table 2 .

Phytochemical screening of different solvent extracts of Buchanania lanzan bark uncovered the existence of various phytochemicals as presented in Table 2. In particular the ethanolic and ethyl acetate extracts of Buchanania lanzan bark showed the presence of carbohydrates, alkaloids, flavonoids, saponins, proteins, aminoacids and phenolic compounds. The

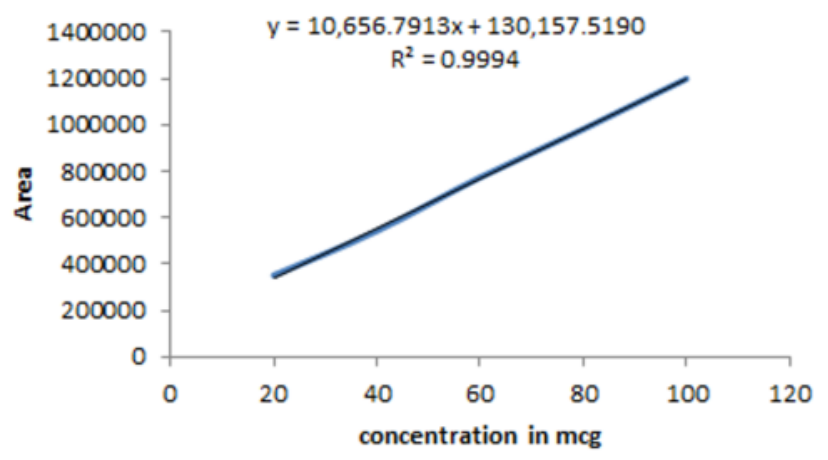

Figure 1. Calibration curve of Gallic acid presence of phytochemical constituents are maximum in ethanolic and ethyl acetate extracts as compared to other extracts, hence further investigations has only been concentrated on the ethanolic and ethyl acetate extract of Buchanania lanzan bark.

\section{Quantification of bioactive compounds}

\section{Total Phenols content}

Numerous phytochemicals which contain phenolic component proved to be possessing significant cytotoxic activity. Phenols are the compound which proves to enhance the body's immune system there by inhibiting the development of new blood vessels (angiogenesis) that is necessary for tumour growth. Hence the quantity of total phenol was estimated by HPLC method using gallic acid as standard drug (Table 3, Figure 1, 2, 3).

The presence of phenolic compounds (TPC) is expressed as mcg of gallic acid equivalent of dry concentrate test utilizing the mathematical expression obtained from the calibration curve: $\mathrm{Y}=10,656.7913 \mathrm{x}+130,157.5190, \mathrm{R} 2=$ 0.999 , where $\mathrm{X}$ is the absorbance and $\mathrm{y}$ is the Gallic acid equivalent (GAE).

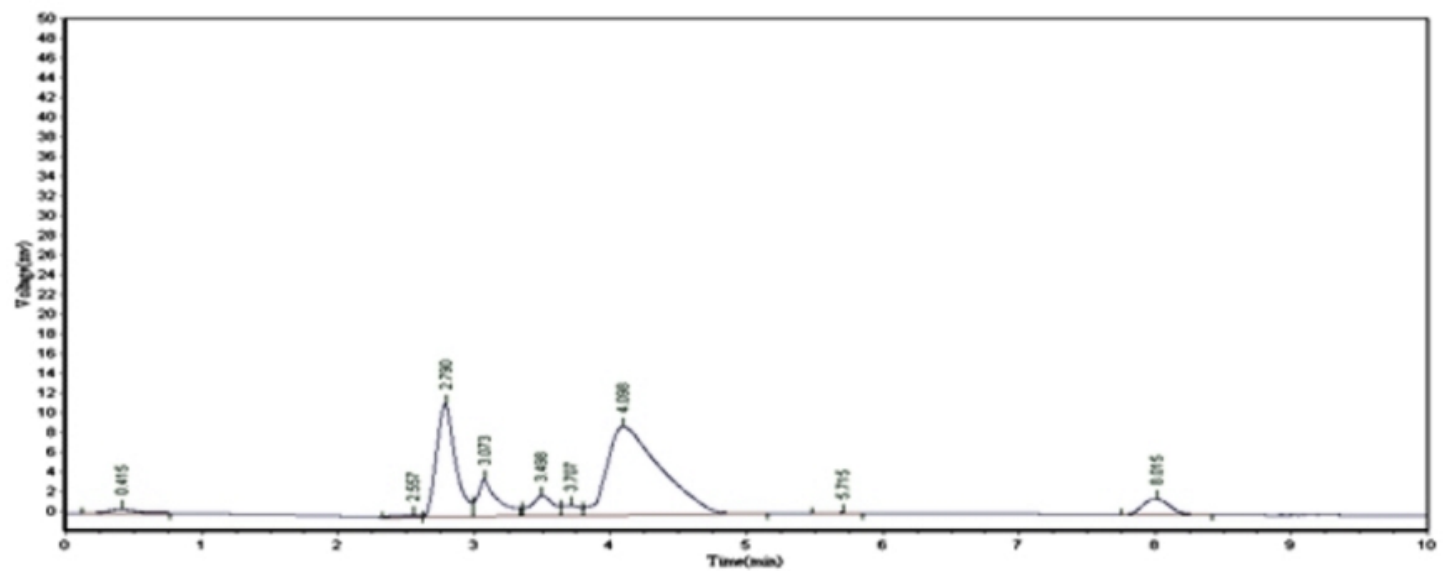

Figure 2. Chromatogram of Galic acid content of Ethanolic Extract of Buchanania lanzan bark

Table 3. Gallic acid content of extracts of Buchanania lanzan bark

\begin{tabular}{|c|c|c|}
\hline Extracts of Buchanania lanzan bark & Ethanolic extract (BE) & Ethyle acetate extract (BEA) \\
\hline Purity & 98 & 98 \\
\hline Sample area & 110509.797 & 870498.25 \\
\hline Standard area & 1198023.625 & 1198023.63 \\
\hline Sample weight in mcg & 1000 & 1000 \\
\hline Standard weight in mcg & 100 & 100 \\
\hline Sample dilution $\mathrm{ml}$ & 1 & 1 \\
\hline Standard dilution $\mathrm{ml}$ & 1 & 1 \\
\hline Content of Gallic acid mcg & 0.903985521 & 7.12079685 \\
\hline
\end{tabular}




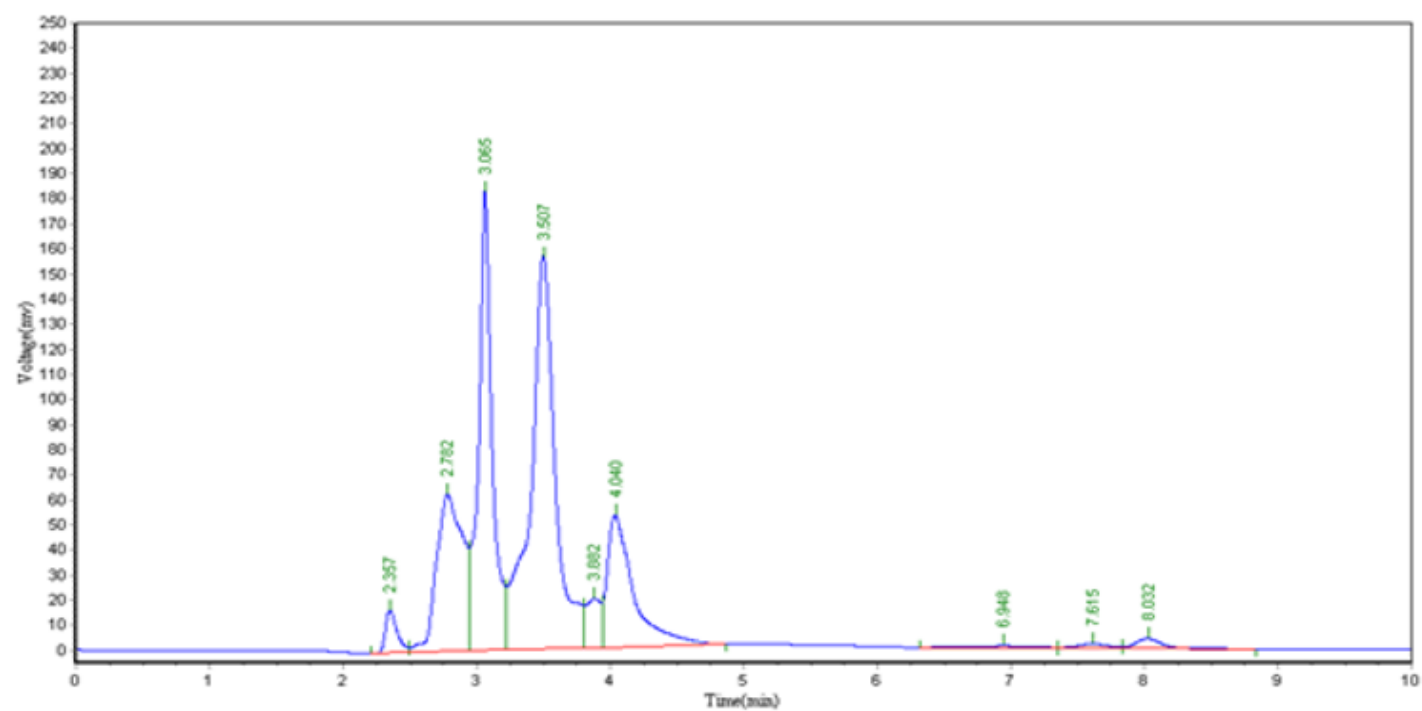

Figure 3. Chromatogram of Galic acid content of ethyl acetate extract of Buchanania lanzan bark

In the present study, the ethyl acetate bark concentrate of Buchanania lanzan displays $7.12 \mathrm{mcg}$ of gallic acid equivalent phenols where as the ethanolic concentrate shows $0.9 \mathrm{mcg}$ of gallic acid equivalent phenols (Table 4, Figure $4 \& 5$ ).

\section{Total flavonoids content}

Flavonoids are polyphenolic compounds that occur ubiquitously

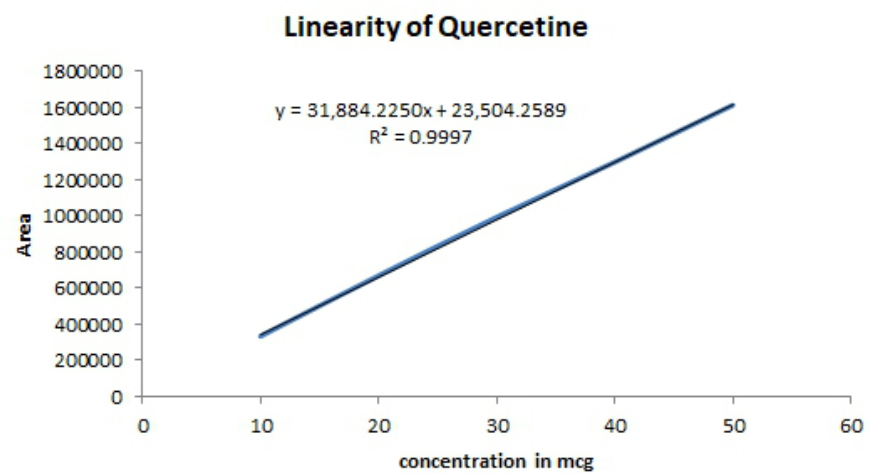

Figure 4. Calibration curve of Quarcetin in foods of plant origin. Flavonoids of the flavone, flavonol, flavanone, and isoflavone classes possess antiproliferative effects in different cancer cell lines and anticancer effects of these polyphenols depend on factors like chemical structure and concentration. Hence quantification of flavonoid content has been done in ethanolic and ethyl acetate extracts of Buchanania lanzan bark by HPLC method using quercetin as standard compound (Table 5, Figure 4).

Absolute concentration of flavonoids was computed as quarcetin proportionate $(\mathrm{mcg})$ utilizing the mathematical statement in light of the calibration curve: $\mathrm{Y}=31,884.2250 \mathrm{x}$ $+23,504.2589, \mathrm{R} 2=0.999$, where $\mathrm{X}$ is the absorbance and $\mathrm{Y}$ is the quarcetin comparable $(\mathrm{QE})$.

The result reveals that the ethyl acetate bark concentrate of Buchanania lanzan exhibits $0.34 \mathrm{mcg}$ of quarcetin equivalent of flavonoids where as the ethanolic concentrate exhibits $0.25 \mathrm{mcg}$ of quarcetin equivalent of flavonoids (Figure 5 \& 6).

The measurement of aggregates of phenols and flavonoid was resolved and it was found that the ethyl acetate

Table 4. Quarcetine content of extracts of Buchanania lanzan bark

\begin{tabular}{|c|c|c|}
\hline Extracts of Buchanania lanzan bark & Ethanolic extract (BE) & Ethyle acetate extract (BEA) \\
\hline purity & 98 & 98 \\
\hline sample area & 850073.375 & 1141022 \\
\hline standard area & 1612042.75 & 1612043 \\
\hline sample weight in mcg & 1000 & 1000 \\
\hline standard weight in mcg & 5 & 5 \\
\hline sample dilution $\mathrm{ml}$ & 1 & 1 \\
\hline standard dilution $\mathrm{ml}$ & 1 & 1 \\
\hline Content of Quercetin mcg & 0.258390141 & 0.346828 \\
\hline
\end{tabular}




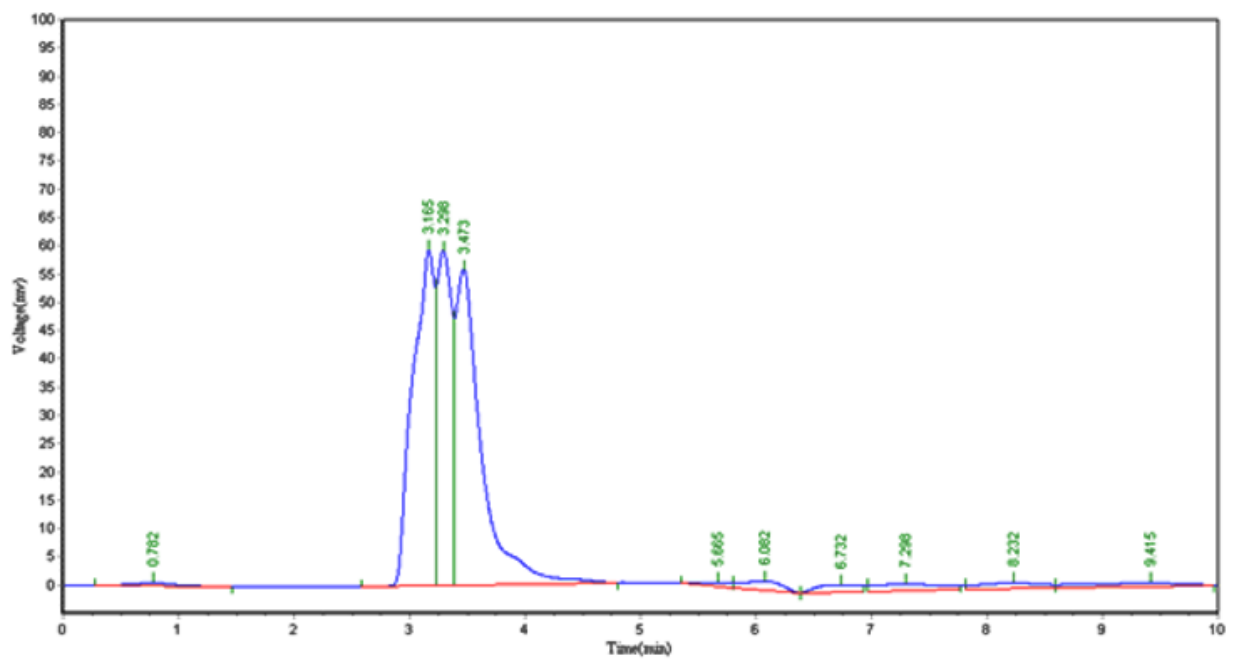

Figure 5. Chromatogram of Quarcetine content of Etnanolic extract of Buchanania lanzan bark

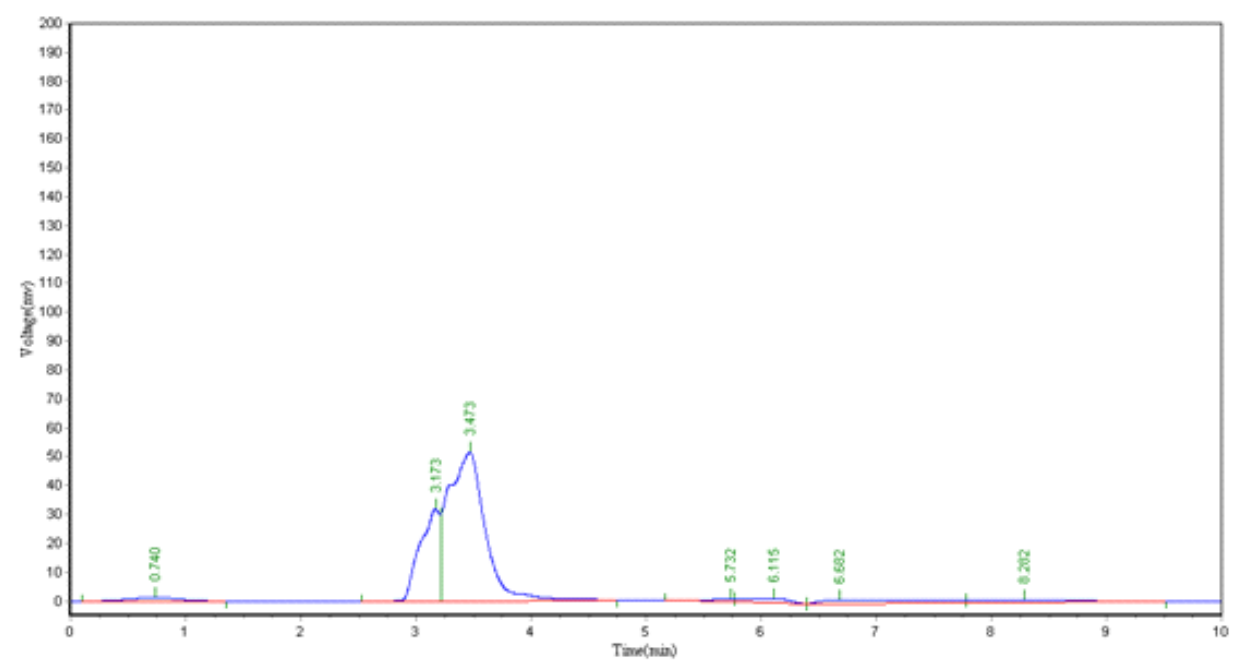

Figure 6. Chromatogram of Quercetin content of ethyl acetate extract of Buchanania lanzan bark

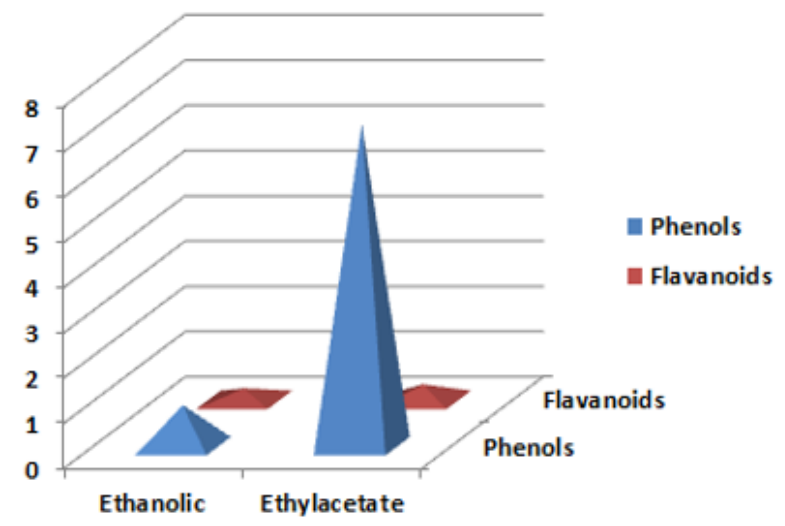

Figure 7. Comparative representation of total flavonoid and phenolic content in ethanolic and ethyl acetate Extract of Buchanania lanzan bark concentrate of Buchanania lanzan bark has higher contents of phenols and flavonoids in comparison to ethanolic extract. Hence more emphasis can be given to the ethyl extract for in-vitro and in-vivo to show plants cytotoxic potential in future (Figure7).

\section{Conclusion}

Herbal drugs can play important beneficial roles in human nutrition and health status as it influence the many immunological events associated with the development and progression of cancer. Diet and health relationships are very complex, as food items usually act through multiple pathways and each ingredient can have different molecular targets. Flavonoids and Phenols have the potential of modulating many biological events in cancer such as apoptosis, vascularization, cell differentiation, cell proliferation, etc hence both additive as well as several 
dietary flavonoids and phenols have been reported contributing to the health. The higher content of phenols and flavonoids in Buchanania lanzan bark extracts keep it as a promising anticancerous herbal drug lead in future. However, further efforts are necessary to understand its potential for the cancer prevention in future.

\section{Acknowledgment}

The authors are very grateful to Rajiv Ganghi University of Health and Sciences (RGUHS), Bangalore for providing financial assistance. The authors are also like to thanks Dr. Paadma M Paarakh, Principal of the oxford college of pharmacy, Hongasandra, Bangalore for providing laboratory facilities to carry out work and Dr. Rajesh shukla for his constant scientific support.

\section{Conflict of interest}

None

\section{References}

Chang H, Mi M, Ling W, Zhu J, Zhang Q, Wei N, Zhou Y, Tang Y, Yuan J. 2008. Structurally related cytotoxic effects of flavonoids on human cancer cells in vitro. Archives of Pharmacal Research, 31(9):1137-44.

Hossein S, Hassanpour M. 2017. Review of cancer from perspective of molecular. Journal of Cancer Research and Practice, 4(4): 127-129.

Jain R, Jain SK. 2015. Effect of Buchanania Lanzan Spreng. bark extract on cyclophosphamide induced genotoxicity and oxidative stress in mice. Asian Pacific Journal of Tropical Medicine, 5(3):187-191.

Kapoor LD. Handbook of Ayurveda Medicinal Plants. CRC Press, 2000; pp 85.

Katrin S. 2014. Cytotoxicity of dietary flavonoids on different human cancer types. Pharmacognosy Reviews, 8(16):122-146.

Kooti W, Servatyari K, Behzadifar M, Nouri B. 2017. Effective Medicinal Plant in Cancer Treatment. Review Study, 22(4): 982-995.

Kumari A, Kakkar P. 2008. Screening of antioxidant potential of selected barks of Indian medicinal plants by multiple in vitro assays. Biomedical and Environmental Sciences, 21(1):24-29.

Kuntz S, Wenzel U, Daniel H. 1999. Comparative analysis of the effects of flavonoids on proliferation, cytotoxicity, and apoptosis in human colon cancer cell lines. European Journal of Nutrition, 38(3): 133-142.

Mehta KS, Mukherjee S, Jaiprakash B. 2011. Anti-inflammatory activity of the methanolic extract of Buchanania Lanzan leaves by carrageenan-induced rat paw oedema method.
International Journal of Pharmaceutical Sciences and Research, 6(2):144-146.

Mehta S, Jaiprakash B, Nayeem N. 2011. Isolation and Phytochemical Investigation on leaves of Buchanania lanzan (Chironji). Annals of Biological Research, 2 (3):469-473.

Pattnaik A, Sarkar R, Sharma A. 2013. Pharmacological Studies on Buchanania Lanzan Spreng.-A focus on wound healing with particular reference to anti-biofilm properties, Asian Pacific Journal of Tropical Biomedicine, 3(12): 967-974.

Perveen S, Al-Taweel AM. 2017. Phenolic Compounds from the Natural Sources and Their Cytotoxicity, 2(3): 21-22.

Puri A, Sahai R, Singh KL, Saxena RP, Tandon JS, Saxena KC. 2000 Immunostimulant activity of dry fruits and plant materials used in Indian traditional medical system for mothers after child birth and invalids. Journal of Ethnopharmacology, 71(1-2):89-92.

Rai MK. 2010. Review: biotechnological strategies for conservation of rare and endangered medicinal plants. Biodiversitas, 11(3):157-166.

Selassie CD, Kapur S, Verma RP, Rosario M. 2005. Cellular apoptosis and cytotoxicity of phenolic compounds: a quantitative structure-activity relationship study. Journal of Medicinal Chemistry, 48(23):7234-42.

Warokar AS, Ghante MH, Duragkar NJ, Bhusari KP. 2010. Anti-inflammatory and antioxidant activities of methanolic extract of Buchanania Lanzan kernel. Indian Journal of Pharmaceutical Education and Research, 44(4):363-368. 